\title{
Does Border Strength Affect Job Satisfaction and Organizational Citizenship Behavior:
}

\author{
Empirical Studies at Higher-Educational Institutions
}

\author{
Nilawati Fiernaningsih*, Pudji Herijanto \\ Department of Business Administration \\ Malang State Polytechnic \\ Malang, Indonesia \\ *nilafh@polinema.ac.id, pudji.herijanto@polinema.ac.id
}

\begin{abstract}
This study aims to examine and analyze the effect of border strength on job satisfaction and organizational citizenship behavior based on gender and marital status as a control for permanent lecturers at the State Polytechnic of Malang, Indonesia. The number of respondents in this study was 200 people chosen by simple random sampling. The analytical tool used is SEM with the WarpPLS approach. The results show that border strength has a significant negative effect on job satisfaction. Border strength also has a considerable impact on organizational citizenship behavior. Job satisfaction, on the other hand, has a significant positive impact on organizational citizenship behavior. The results of this study are beneficial for State Polytechnic of Malang's leaders in designing border strength policies so that the lecturers feel comfortable in living their work-family life and increase the different role of lecturers for the institution.
\end{abstract}

Keywords-border strength, job satisfaction, organizational citizenship behaviour

\section{INTRODUCTION}

Lecturers hold a central role as a pillar of institutional development in Higher-educational institutions like College or University. Professionalism, a sense of care for the institution, and citizenship behavior as part of the organization must continue to be fostered. Organizational Citizenship Behavior (OCB) plays an important role in improving organizational competitiveness and performance. OCB is useful in improving employee and organizational performance, saving resources, increasing adaptability, and reducing turnover intention [1]. Therefore, OCB has a strategic value for the future of HigherEducational Institutions.

This research develops the conceptual framework, examines, and analyzes the factors that build OCB. This study focused on OCB antecedent factors such as border strength and job satisfaction. Border strength is important to assess its influence on OCB because it is predicted to improve employee moods and create better communication with family so as to encourage positive behavior in the form of OCB. Meanwhile, job satisfaction is also critical to learn considering the higher job demands, and job satisfaction can be predicted to have implications for OCB behavior. The uniqueness of this research lies in the focus and conceptual model that is built in this study. Research on the influence of Border Strength and job satisfaction on OCB in Higher-Educational Institutions is still very limited, so this is one of the reasons why this research is important. Policy formulation at Higher Education Institute based on border strength theory [2] deserves attention in order to design policy formulations that facilitate lecturers to be more comfortable in working, so that positive attitudes and behaviors for extra work are done voluntarily.

\section{LITERATURE REVIEW}

\section{A. Border Strenght}

Clark [2] developed the Border Theory which explains how the segmentation and integration of the family domain and the work domain, creating and managing boder, as well as the relationship between border crossers and how work life balance is created. The central concept of Border Theory and its characteristics include: the work and home domains, the borders between work and home, the border crossers, the border keepers, other important domains members. Similarity of domains becomes an important study in Border Theory. The realm of work and realm of home can be referred to as two different domains related to different rules, mindset, and behaviors. The difference between work and home can be classified in two different ways, such as the difference in valuable goals and the difference in a valued way [3]. The purpose of work is mainly to provide satisfaction, provide income and provide a sense of achievement, meanwhile the goal of home life satisfaction is achieving harmonious relationships and personal happiness [4]. Means of achieving goals in an organization create a culture in which certain behaviors and ways of thinking are encouraged. and facilities to achieve goals in an organization create a culture in which certain behaviors and ways of thinking are encouraged. In the work environment, employees are required to be cheerful and 
friendly to customers. Meanwhile in the family environment may be different, someone emphasizes honesty emotions. An employee is required to be "responsible" and "competent" in the work environment, while "loving" and "giving" are ways to achieve goals in the family environment.

Border is the demarcation line between domains that determines the point at which behavior relevant to the domain begins or ends [2]. These boundaries consist of three main forms: physical, temporal and psychological. Physical boundaries, such as walls of the workplace or walls of the house, determine where behavior relevant to the realm occurs. Temporal boundaries, such as setting working hours, separate when work is done when family responsibilities can be taken care of. Psychological boundaries are rules made by individuals that determine when mindset, behavior patterns, and emotions are appropriate for one domain but not for another. Clark [2] measures border strength with three indicators such as permeability, flexibility, and blending. Permeability shows the extent to which elements of the work domain able to enter the family domain and vice versa [5]. Permeable borders create opportunities for employees to take emergency actions for their personal / family interests when they are at work. Employees have the opportunity to take emergency measures for the benefit of their families without reducing their duties and responsibilities as employees. Flexibility is the extent to which borders can adjust, depending on the demands of one domain or another domain [6]. The company provides opportunities for employees to work flexibly so that employees are able to balance work with their personal lives. For example, companies provide flexibility to employees to choose work hours and workplaces. When psychological boundaries are flexible, employees feel comfortable working at home and thinking about home when working. The principle is that employees feel given flexibility in fulfilling their obligations so they have the opportunity to balance work life with family life. Blending means the combination of work domain and family domain. Employees are given the opportunity to combine work tasks while being able to live a pleasant personal life. High permeability and flexibility make it easy to integrate work and family matters. Easily combine work with family matters shows a weak border and this facilitates the formation of work life balance.

\section{B. Job Satisfaction}

Job satisfaction is an evaluation that describes someone's feelings of attitude, happy or not happy, satisfied, or dissatisfied at work [7]. Another opinion was expressed by Hasibuan [8] that job satisfaction is a pleasant emotional attitude and loves his job. This attitude is reflected by work morale, discipline, and work performance. Job satisfaction is enjoyed at work, outside work, and a combination of inside and outside work.

Luthans [9] provides a comprehensive definition of job satisfaction, which includes cognitive, affective, and evaluative reactions or attitudes and states that job satisfaction is a happy emotional state or positive emotion from assessing a person's job or work experience. Job satisfaction is the result of employees' perceptions of how well their job provides things that are considered necessary. In general, job satisfaction is the most important and often studied attitude.

\section{Organizational Citizenship Behaviour}

Organ [10] defines OCB as behavior that is an individual choice and initiative, not related to the organization's formal reward system, but in the aggregate to increase organizational effectiveness. This means that the behavior is not included in the work requirements or employee job descriptions, so that, if not displayed, no punishment is given [11]. OCB involves a number of behaviors, including helping others, volunteering for extra tasks, complying with rules and procedures at work. These behaviors illustrate "the employee added value" and is one of the forms of prosocial behavior, the social behavior of positive, constructive and meaningful help [12]. Thus OCB is a functional, extra-role, pro-social behavior that directs individuals, groups or organizations. Robbins [13] suggests the importance of employees' behavior who want to work beyond the job description. Successful organizations need employees who will do more than their formal duties and are willing to deliver performance that exceeds expectations. In the dynamic world of work as it is today, where tasks are increasingly being done in teams, flexibility is very important. The organization wants employees who are willing to perform tasks that are not listed in their job descriptions. Robbins and Judge [14] said organizations that have employees who have good OCB, will have better performance than other organizations. Podsakoff et al. [1] divides OCB into seven dimensions, namely behavior to help work pressure, adherence to the organization, sportsmanship, loyalty to the organization, individual initiative, social quality in the organization, and self-development for the benefit of the organization. Meanwhile, Organ [10] developed five OCB indicators, such as altruism, conscientiousness, civic virtue, sportsmanship, and courtesy.

\section{METHODOLOGY}

The population of this research is all permanent lecturers in State Polytechnic of Malang, the total is 385 people. Based on the Slovin formula, it can determine a sample size of 200 people. The sampling technique used is simple random sampling. The questionnaire was used as an instrument for collecting data that was distributed directly or via e-mail to each respondent. Measurement of border strength variables refers to Clark [2], job satisfaction variables refer to the research of Glueck [15], Handoko [16], Husnan [17], and Sarwoto, while OCB variables refer to Organ [10], Yadav and Yangnekar [18], Gonzalez and Garazo [19], Foote and Tang [20], Coyne and Ong [21], Baral and Bhargava [22], and Sharoni et al. [23].

\section{RESULTS AND DISCUSSION}

Based on genders, the sample distribution of this study consisted of $43 \%$ men and $57 \%$ women. Based on marital status, it consists of $51 \%$ married and $49 \%$ unmarried. $36.5 \%$ 
of the sample received additional assignments (structural positions) and $63.5 \%$ did not hold structural positions in Higher-Educational Institutions. The approach used to analyze this research is WarpPLS. Validity and reliability testing is done by using convergent validity, discriminant validity, composite reliability, and Cronbach's alpha for cross checking validity and reliability. The results of the measurement of validity show that the t-test is greater than the t-table (1.96) and AVE in all variables exceeds the estimation of each square so that it meets the convergent validity and discriminant validity. The reliability measurement results show that Composite Reliability> 0.7 and Cronbach's alpha> 0.6, the reliability is fulfilled.

TABLE I. HYPOTHESIS TEST

\begin{tabular}{|c|c|c|c|}
\hline Path & $\beta$ & $p$-Value & Claim \\
\hline $\begin{array}{l}\text { (H1) Border strength } \rightarrow \\
\text { Work-life balance }\end{array}$ & -0.768 & $<0.001$ & Supported \\
\hline $\begin{array}{lll}(\mathrm{H} 2) & \text { Border } & \text { strength } \\
\mathrm{OCB} & & \end{array}$ & -0.374 & $<0.001$ & Supported \\
\hline $\begin{array}{lll}(\mathrm{H} 3) & \text { Work-life } & \text { balance } \\
\rightarrow \text { OCB } & & \end{array}$ & 0.469 & $<0.001$ & Supported \\
\hline
\end{tabular}

H1 predicts that border strength affects job satisfaction. The results show that border strength has a significant and positive effect on job satisfaction. $\mathrm{H} 2$ predicts that border strength has an effect on OCB. The results show that border strength has a significant negative effect on OCB (path coefficient $=-0.374, p$ $<0.01)$. H3 predicts that job satisfaction affects OCB. The results showed that border strength had a significant and positive effect on OCB (path coefficient $=0.469, \mathrm{p}<0.01$ ).

\section{CONCLUSION AND SUGgestion}

These results indicate that border strength has a significant and positive effect on job satisfaction. The stronger the border, the higher the job satisfaction felt by the lecturer. This shows that the frame facilitates job satisfaction, as expressed by Clark (2000). In this case, a weak border is relevant to be used to improve job satisfaction among lecturers. Institutions understand urgent personal interests and provide opportunities for lecturers to take emergency measures for personal gain even during working hours. Institutions provide flexibility to her job until they feel satisfied, so they have a pleasant life.

These results indicate that border strength has a significant negative effect on OCB. The stronger the border, the lower the OCB. Vice versa, the weaker the border the higher OCB. Lecturers' perceptions of institutional policies influence their behavior. This is relevant to social exchange theory [24] that OCB is a remuneration for the benefits received by lecturers from institutions. When the lecturer considers that the institution has implemented useful policies, the lecturer responds with behaviors that benefit the institution. Lecturers not only fulfill the obligations of teaching, research, and community service, but also help colleagues in fulfilling their obligations so that, in general, will improve the institution's performance. Lecturers also actively involve themselves in campus activities aimed at improving the performance of the institution. These results indicate that job satisfaction has a significant positive effect on OCB. The higher the job satisfaction, the higher the OCB, and the lower the job satisfaction, the lower the OCB. The purpose of working employees is to get financial benefits, but employees also expect their job satisfaction. The balance between job satisfaction is one of the employees' goals, so when they get that, it means the balance is considered a virtue. Lecturers are also involved in family activities not to lose important family moments such as birthdays, vacations, or other family events, so they feel satisfied with their job. Finally, the lecturer feels happy with job satisfaction between work life and family.

The results of this study have weaknesses. First, this research is cross sectional, so it has not been able to generalize for the entire time period. Secondly, this research was conducted at one of the higher education institutions in Indonesia which is State Polytechnic of Malang, the same research is still needed in several different places. Third, this study has not analyzed the role of individual characteristics in the tested conceptual models. Future research is expected to be carried out at different institutions and locations. In addition, further research can include individual characteristics (such as gender, marital status, and workload) in the research model as a control, so that more specific results will be obtained.

\section{ACKNOWLEDGMENT}

The author would like to thank who is involved in research activities.

\section{REFERENCES}

[1] P.M. Podsakoff, S.B. Mackenzie, J.B. Paine, and D.G. Bachrach, "Organizational citizenship behaviours: a critical review of the theoretical and empirical literature and suggestions for future research" Journal of Management, vol. 26, no. 3, pp. 513-563, 2000.

[2] S.C. Clark, "Work/family border theory: A new theory of work/family balance," Human Relations Journal, vol. 53, no. 6, pp. 747-770, 2000.

[3] M. Rokeach, The nature of Human Value. New York: Free Press, 1973.

[4] S.C. Clark and P.M.K. Farmer, "Living into different world: Measuring cultural and value differences between work and home, and their effect on border-crossing," Paper presented at the Institute of Behavioural and Applied Management Annual Conference, Orlando FL, 1998.

[5] B. Beach, Integrating work and family life. Albany, NY: State University of New York Press, 1989.

[6] D.T. Hall and J. Richter, "Balancing work life and home life: What can organization do to help?" Academy of Management Executive, vol. 11, pp. 213-223, 1988.

[7] V. Rivai and A.F.M. Basri, Performance Appraisal: Sistem yang tepat untuk menilai kinerja karyawan dan meningkatkan daya saing perusahaan. PT RajaGrafindo Persada, 2005

[8] M.S.P. Hasibuan, Manajemen Sumber Daya Manusia Edisi Revisi. Jakarta: Bumi Aksara, 2010.

[9] F. Luthans, Organizational behavior (12th ed.). New York, NY McGraw-Hill Irwin Publications, 2011. 
[10] D.W. Organ, Organizational Citizenship Behavior: The Good Soldier Syndrome, Heath, Lexington, MA, 1988.

[11] F. Novliadi, "Organizational Citizenship Behaviour Karyawan Ditinjau dari Persepsi terhadap Kualitas Interaksi Atasan-Bawahan dan Persepsi terhadap Dukungan Organisasinal," Psikologia Jurnal Pemikiran \& Penelitian Psikologi, vol. 2, no. 1, pp. 39-46, 2007.

[12] C.A. Smith, D. Organ, and J.P. Near, "Organizational Citizenship Behaviour: Its Nature and Antecedents," Journal of Applied Psychology, vol. 68, no. 4, pp. 653-663, 1983.

[13] S. Robbins, Prinsip-prinsip Perilaku Organisasi. 5th Edition. Jakarta: Erlangga, 2001.

[14] S. Robbins and M. Coulter, Management. 9th ed. Australia: Prentice Hall Pearson Education International, 2012.

[15] L.R. Jauch and W.F. Glueck, Manajemen dan Strategis Kebijakan Perusahaan. Jakarta: Erlangga, 1989.

[16] T.H. Handoko, Manajemen. BPFE: Yogyakarta, 1995.

[17] H. Ranupandojo and S. Husnan, Manajemen Personalia, 4th Edition. Yogyakarta: BPFE UGM, 1994.

[18] M. Yadav and S. Rangnekar, "Supervisory Support and Organizational Citizenship Behaviour," Evidence-based HRM, vol. 3, no. 3, pp. 258278, 2014.
[19] J.V. Gonzalez and T.G. Garazo "Structural Relationship Between Organizational Service Orientation, Contact Employee Job Satisfaction and Citizenship Behaviour," International Journal of Service Industry Management, vol. 17, no. 1, pp. 23-50, 2004.

[20] D.A. Foote and T.L. Lang, "Job satisfaction and organizational citizenship behaviour (OCB) does team commitment make a difference in self-directed teams?" Journal Management Decision, vol. 46, no. 6, pp. 933-947, 2007.

[21] I. Coyne and T. Ong, "Organizational Citizenship Behaviour and Turnover Intention: A Cross-Cultural Study," International Journal of Human Resource Management, vol. 18, no. 6, pp. 1085-1097, 2007.

[22] R. Baral and S. Bhargava, "Work Family Enrichment as A Mediator Between Organizational Interventions for Work life Balance and Job Outcomes," Journal of Managerial Psychology, vol. 25, no. 3, pp. 274$300,2008$.

[23] G. Sharoni, A. Tziner, E.C. Fein, T. Shultz, K. Shaul, and Zilberman, "Organizational Citizenship Behaviour and Turnover Intentions: Do Organizational Culture and Justice Moderate Their Relationship?" Journal of Applied Social Psychology, vol. 42, no. S1, pp. E267-E294, 2010.

[24] P.M. Blau, Exchange and Power in Social Life. NewYork: JohnWiley \& Son, 1964s 